\title{
PEMBENTUK ATRIBUT LEKSIKON JAGUNG DALAM MASYARAKAT TUTUR JAWA
}

Fitri Febriyanti dan Sulistyowati

Program Studi Ilmu Linguistik, Universitas Gadjah Mada

Jalan Sosio Humaniora, Bulaksumur, Sleman, Yogyakarta

Surel: fitrifebriy anti94@gmail.com

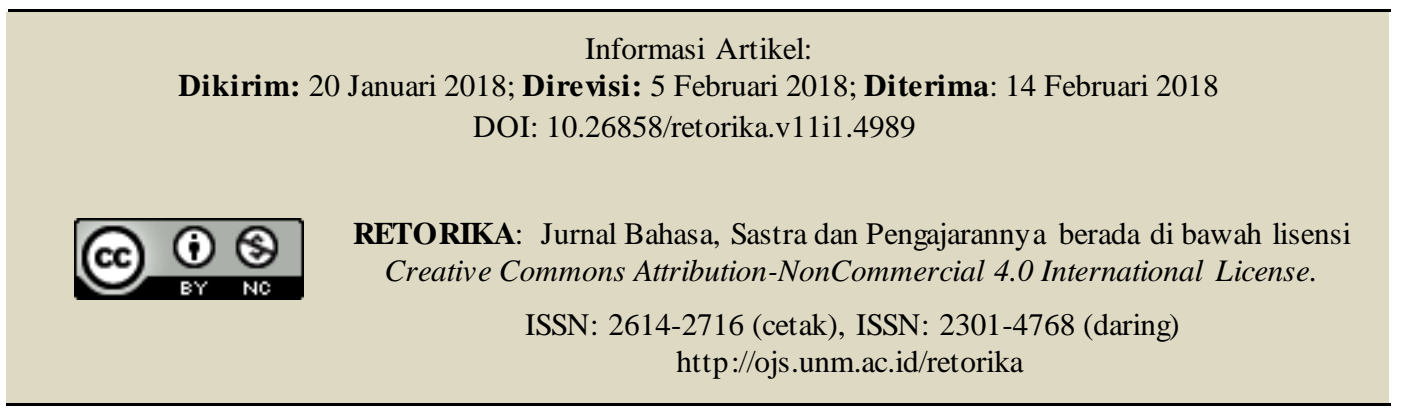

\begin{abstract}
The formation of corn's lexicons in Javanese. This study aims to describe the constituent elements and the type of reference from corn's lexicons in Javanese. The type of this study is qualitative descriptive by using semantics theory approach. Methods of data collection are literature study and interview. The source of data comes from informant who's working as farmer in Sragen and Pemalang regency. The numbers of informants are three people in each regency. The data were analyzed by 'teknik pilah' followed by 'teknik hubung banding'. The results shows (1) the forming element of attributes are word and phrase, and (2) the type of reference consists of three categories, i.e. functions of maize plants, morphology of maize plants, and cultivation of maize plants.
\end{abstract}

\begin{abstract}
Abstrak: Pembentuk Atribut Leksikon Jagung dalam Masyarakat Tutur Jawa. Penelitian ini bertujuan mendeskripsikan unsur pembentuk dan referen leksikon jagung dalam masyarakat Jawa. Penelitian ini didesain dekriptif kualitatif dengan menggunakan pendekatan teori semantik. Metode pengumpulan data berupa studi pustaka dan wawancara. Data dari informan bersumber dari petani di Kabupaten Sragen dan Kabupaten Pemalang. Jumlah informan berjumlah tiga orang pada daerah masing-masing. Data dianalisis dengan teknik pilah yang dilanjutkan dengan teknik hubung banding. Hasil penelitian menunjukkan (1) unsur pembentuk atribut berupa kata dan frasa dan (2) jenis referen terdiri atas tiga kategori, yakni fungsi tanaman jagung, morfologi tanaman jagung, dan cara budi daya tanaman jagung.
\end{abstract}

Kata Kunci: atribut, jagung, leksikon, masyarakat Jawa, semantik 
Masyarakat Jawa sebagai salah satu masyarakat berbudaya, sangat produktif dalam menghasilkan ilmu pengetahuan sejak zaman dahulu silam. Salah satu hasil ilmu pengetahuan yang sangat dekat dengan kehidupan masyarakat Jawa ialah leksikon. Leksikon ialah satu himpunan kata-kata dan idiom bahasa yang digunakan sesuai bidang pemakaiannya (Parera, 1993). Kehadiran leksikon dalam masyarakat berasal dari pola pikir dan pandangan masyarakat terhadap lingkungan yang mengelilinginya. Leksikon yang masih ditemui dalam masyarakat Jawa ialah leksikon dalam hal tumbuhan dan cara membudidayakannya. Leksikon yang ada mencerminkan aktivitas dan budaya masyarakat.

Penelitian terdahulu yang membahas tentang tumbuhan dalam bahasa Jawa telah dilakukan sejumlah peneliti. Suhandano (2000) mengkaji klasifikasi folk biologi daalam bahasa Jawa; Suhandano, dkk. (2004) mengkaji leksikon etnobotani bahasa Jawa; Suhandano (2004) mengkaji klasifikasi tumbuh-tumbuhan dalam bahasa Jawa; Haryati (2007) mengkaji ungkapan etnis petani Jawa dengan menggunakan kajian sosiolinguistik; dan Suhandano (2007) mengkaji tumbuhan wit dan suket dalam bahasa Jawa. Bukan hanya bahasa Jawa, adanya hubungan antara tumbuhan dengan bahasa lain yang digunakan oleh masyarakat ditunjukkan pada penelitian bahasa minoritas hamap dalam perkebunan jagung (Tondo, 2012). Seluruh artikel ilmiah yang terkait tersebut mencerminkan cara masyarakat Jawa membudidayakan beberapa tumbuhan sehingga muncul beberapa leksikon khusus sebagai lambang klasifikasi dari penuturnya.

Penelitian tentang tumbuhan dalam bahasa Jawa maupun bahasa daerah lain di Indonesia masih jarang ditemukan. Sebagai masyarakat agraris, petani Jawa mampu mengolah lahannya untuk menghasilkan panen dari beberapa tumbuhtumbuhan. Selain tanaman padi, terdapat pula tanaman jagung sebagai salah satu bahan makanan yang cukup besar dihasilkan oleh petani Jawa.

Dalam penelitian ini, jagung secara khusus disebut sebagai tanaman karena tumbuhan yang biasa ditanam orang, sedangkan pengertian tumbuhan ialah segala sesuatu yang tumbuh. Jagung sebagai tanaman mempunyai bentuk luar yang menyusunnya (morfologi) seperti akar, batang, daun, bunga, dan tongkol. Jenis leksikon jagung dalam bahasa Indonesia mencakup jagung manis, jagung titi, dan jagung tumbuk. Pada penelitian ini hanya digunakan leksikon jagung sejenis jagung manis yang memiliki padanan kata dalam klasfikasi jagung secara biologi. Leksikon jagung titi dan jagung tumbuk tidak dibahas karena kedua leksikon tersebut berupa hasil olahan tanaman jagung.

Suhandano (2004:237) menggolongkan tanaman jagung sebagai wit karena berbatang keras dan berfungsi sebagai penghasil bahan makanan. Penelitian Suhandano (2004:238) menjelaskan tumbuh-tumbuhan yang secara budaya memiliki peran menonjol dalam kehidupan, misalnya penghasil bahan makanan dapat dirinci sampai kategori spesifik dan varietal. Wijana (2015:50) menjelaskan bahwa ahli bahasa cenderung menggunakan cara klasifikasi yang mirip dengan cara klasifikasi masyarakat dalam mengklasifikasi fenomena alam. Cara yang dilakukan dalam hal klasifikasi tersebut disebut sebagai taksonomi rakyat (folk taxonomy). Analisis data menggunakan ilmu semantik, yakni (1) ilmu tentang makna kata dan kalimat; pengetahuan mengenai selukbeluk dan pergeseran arti kata; (2) bagian struktur bahasa yang berhubungan dengan makna ungkapan atau struktur makna suatu wicara.

Hal ini berkaitan dengan teori yang digunakan berupa medan makna. Medan makna ialah ranah atau bidang arti yang dimiliki oleh butirbutir leksikal (Wijana, 2015:48). Medan makna yang berkaitan langsung dengan data penelitian ini adalah hiponimi. Dalam hiponimi terdapat hubungan antara superordinat dan subordinat. Superordinat dapat merupakan leksem yang memiliki makna yang lebih umum. Dalam penelitian ini yang dimaksud superordinat adalah jagung. Selanjutnya, subordinatnya adalah leksem yang memiliki makna lebih khusus. Dalam penelitian ini yang disebut subordinat adalah blorok/ slenggreng, genjah, hibrida, jalawara, kertas, manis, kristal, unyil, canthel, pakan, pioner. Dengan demikian dapat dikatakan bahwa superordinat sebagai genus dan subordinat yang merupakan anggota kelasnya.

Seluruh jenis jagung yang dianggap sebagai data ialah jagung yang memiliki padanannya secara klasifikasi biologi. Data penelitian terdahulu milik Suhandano (2007:116) mampu mengumpulkan leksikon jagung sebanyak 17 buah. Perbedaan penelitian ini dengan penelitian tersebut ialah objek penelitian yang dibatasi pada leksikon jagung saja Selain itu, kajian analisis yang digunakan dalam penelitian ini berupa kajian semantik. Data dilengkapi hasil pengamatan yang dilakukan Kabupaten Sragen dan Pemalang. 
Penelitian ini menggunakan pendekatan semantik untuk mengetahui penamaan jagung yang berasal dari masyarakat. Ilmu Semantik adalah teori makna atau teori arti (Verhaar, 1981:124). Penggunaan ilmu semantik dalam membedah data penelitian ini bermanfaat agar pandangan masyarakat Jawa dapat teridentifikasi melalui leksikon jagung. Leksikon jagung secara kebahasaan diidentifikasi melalui bentuk atribut dan jenis referen yang digunakan dalam atribut. Hal pertama yang dilakukan dalam mengklasifikasi data leksikon jagung ialah mencari makna leksikal.

Menurut Verhaar (2012:389) makna leksikal dipandang sebagai sifat kata sebagai unsur leksikal, yakni kemampuan kata untuk mengacu pada makna tertentu. Pada data leksikon jagung, masing-masing atribut dicari artinya dalam kamus berbahasa Jawa (Bausastra Jawa) maupun Kamus Besar Bahasa Indonesia (KBBI). Atribut yang memiliki arti dalam kamus tersebut berperan dasar dalam memahami pandangan masyarakat melalui leksikon. Atribut tersebut berfungsi sebagai identitas untuk membedakannya dengan jenis yang lain, seperti atribut jumlah memiliki fungsi memberikan identifikasi jumlah terhadap kata-kata benda yang ditandainya (Wijana, 2015: 78).

Leksikon yang dipilih oleh masyarakat memiliki referen sebagai makna yang diacu. Lebih lanjut, Verhaar (2012) menjelaskan referen berhubungan erat dengan makna dan merupakan salah satu sifat dari makna leksikal. Wijana (2015: 70) mendeskripsi referen sebagai kenyataan luar bahasa yang bersifat eksternal, tidak ada dalam bahasa. Jenis referen telah dikelompokkan oleh Wijana (2015:73-76), yakni referen unik dan referen tak unik, referen abstrak dan referen konkret, serta referen terhitung dan referen tak terhitung. Seluruh jenis referen tersebut berasal dari tiga macam jenis acuan, yakni kata nama, kata ganti, dan frase benda (Wijana, 2015:77). Pada penelitian ini referen mengacu pada frase benda yang memiliki kata pusat berupa kata jagung. Adanya kata pusat berupa kata jagung menunjukkan adanya hubungan hiponimi antara masingmasing leksikon jagung. Konsep hiponimi didasarkan pada pandangan Djajasudarma (2012:72).

Penelitian ini dilakukan dalam rangka mengetahui adanya hubungan dalam leksikon jagung. Hubungan tersebut nampak dari penggunaan leksikon dan pemaknaannya yang muncul dalam masyarakat Jawa. Secara praktis, penelitian ini bermanfaat sebagai inventarisasi leksikon-lek- sikon tradisional yang masih terjaga pada petani jagung masyarakat Jawa. Hasil yang ditemukan dapat dijadikan sebagai langkah pelestarian lingkungan melalui leksikon tradisional yang muncul dalam budi daya dan diversifikasi tanaman jagung. Berdasarkan latar belakang tersebut, penelitian ini adalah pengamatan awal pada leksikon jagung yang bertujuan untuk mengetahui bentuk dan acuan referen pada leksikon jagung.

\section{METODE}

Jenis penelitian adalah dekriptif kualitatif. Hasil penelitian menjelaskan leksikon jagung dalam masyarakat Jawa yang terdiri dari susunan kata. Metode pengumpulan data berupa studi pustaka dan wawancara. Studi pustaka dilakukan untuk mengumpulkan data dari hasil penelitian terdahulu. Wawancara diperlukan untuk mengumpulkan data dari informan, yakni petani di Kabupaten Sragen dan Kabupaten Pemalang. Jumlah informan pada daerah berjumlah tiga orang yang berprofesi sebagai petani. Informasi dipilih dengan kriteria (1) dapat berkomunikasi secara baik dan jelas, (2) petani jagung yang produktif menghasilkan jagung secara konsisten minimal lima tahun berturut-turut, (3) informan berbahasa ibu bahasa Jawa, dan (4) informan berusia 30-65 tahun. Data berupa frasa nomina yang berpusat pada kata jagung dan memiliki atribut yang beraneka ragam. Atribut tersebut merupakan identitas dari hiponim, yakni hubungan antara genus dengan anggota kelas atau hubungan antara satuan bermakna umum dengan satuan bermakna khusus(Wijana, 2016: 93).

Metode padan digunakan untuk menganalisis data dengan teknik dasar berupa pilah referensial. Hal ini dilakukan karena data dapat dipilah berdasarkan atribut yang menjadi referensinya (Sudaryanto, 2015). Metode padan dipilih untuk mengetahui makna referensial yang terkandung dalam leksikon jagung dengan cara melihat padanan maknanya di dalam Kamus Basa Jawa (Bausastra Jawa) dari Tim Balai Bahasa Yogyakarta (2011) dan Kamus Besar Bahasa Indonesia (Sugono, dkk. 2008). Teknik lanjutan yang digunakan berupa teknik hubung banding memperbedakan (HBB) karena mencari perbedaan yang berasal dari kesamaan pokoknya berupa jenis jagung. Leksikon jagung tersebut diklasifikasi berdasarkan bentuk atribut dan tipe referen yang diacu oleh atribut. 


\section{HASIL DAN PEMBAHASAN}

Melalui studi ini telah dikumpulkan 31 leksikon jagung. Dari segi kebahasaan unsur yang terkandung dalam leksikon ialah frasa nomina dengan unsur pusat kata 'jagung'. Leksikon tersebut dipilih berdasarkan penyebutan dan penamaan yang berasal dari masyarakat serta memiliki kesamaan atau padanannya secara biologi. Data penelitian terdahulu milik Suhandano (2007: 116) mampu mengumpulkan leksikon jagung se banyak 17 buah, yakni jagung blorok/slenggreng, jagung genjah, jagung hibrida, jagung jalawara, jagung kertas, jagung konyit, jagung metro, jagung pari, jagung putih, jagung blorok genjah, jagung blorok jero, jagung genjah kencur, jagung genjah menthel, jagung putih genjah, jagung putih genjah kodhok, jagung putih genjah penjalin, jagung putih jero. Data penelitian terkumpul leksikon jagung di Kabupaten Sragen berupa jagung hibrida, jagung manis, jagung kristal, jagung unyil, jagung canthel, jagung tongkol dua, jagung tongkol tiga, jagung tongkol empat. Data penelitian di Kabupaten Pemalang ialah jagung hibrida, jagung manis, jagung pakan, jagung pioner, jagung bisi 2, jagung bisi 18. Paparan hasil dan pembahasan penelitian terdiri atas dua bagian penting, yakni unsur pembentuk atribut dan jenis referen dalam pembentukan atribut.

\section{Unsur Pembentuk Atribut}

Dari segi kebahasaan, leksikon jagung dapat diklasifikasi berdasarkan unsur pembentuk atribut. Unsur penyusun leksikon yang ditemukan terdiri atas sebuah kata, frasa, maupun kata majemuk. Penentuan unsur pembentuk tersebut dapat diketahui melalui proses pembentukan leksikon yang berasal dari penamaan jenis tanaman jagung oleh masyarakat. Berdasarkan data yang telah dikumpulkan, kata 'jagung' sebagai unsur pusat dapat diiringi dengan atribut yang berbentuk kata dan frasa.

\section{Unsur Pembentuk Atribut Berunsur Kata}

Leksikon jagung berupa frasa nomina yang berpusat pada kata jagung diikuti atribut yang berjumlah satu kata. Bentuk leksikon yang dimaksud adalah jagung blorok/slenggreng, jagung genjah, jagung hibrida, jagung jalawara, jagung kertas, jagung manis, jagung kristal, jagung unyil, jagung canthel, jagung pakan, jagung pioner, jagung konyit, jagung metro, jagung pari, jagung putih. Bentuk atribut yang dianalisis berupa blorok/slenggreng, genjah, hibrida, jalawara, kertas, manis, kristal, unyil, canthel, pakan, pioner, konyit, metro, pari, putih.

Kata blorok/slenggreng berasal dari bahasa Jawa yang berarti saemper blirik nanging gedhe corake (tumrap ulesing pitik) 'seperti bercorak lurik tetapi coraknya berukuran besar'. Sebagai kata sifat, kata blorok berfungsi untuk mengelompokkan jenis jagung berdasarkan jenis corak yang nampak pada warna biji jagung. Secara umum warna jagung lainnya juga dikelompokkan sebagai jagung putih.

Kata putih memiliki arti (1) warna dasar yang serupa dengan warna kapas: (2) mengandung atau memperlihatkan warna yang serupa warna kapas; (3) murni; suci; tidak ternoda; (4) pucat (tentang wajah). Melalui pengertian tersebut, jagung putih dikelompokkan berdasarkan warna biji jagung yang dihasilkan. Selain warna putih dan blorok, jagung dapat dikelompokkan sebagai jagung konyit.

Kata konyit berasal dari kata 'kunyit' yang memiliki arti (1) tumbuhan, suku Zingiberaceae, marga Curcuma, banyak digunakan dalam masakan, misalnya sebagai bumbu penyedap, pemberi warna kuning, dan dapat membuat makanan lebih awet, dapat juga digunakan sebagai obat; Curcuma domestica atau Curcuma longa; (2) umbi kunyi. Dalam kaitannya dengan leksikon jagung, pengertian konyit yang dimaksud ialah jagung yang memiliki warna kuning, seperti kunyit. Selain berkaitan dengan warna, leksikon jagung yang berunsur kata juga memiliki atribut dari kata yang dipadankan dengan kata lain, seperti jagung pari, jagung kristal, jagung unyil, dan jagung kertas.

Kata pari berasal dari bahasa Jawa 'padi', memiliki arti (1) tumbuhan yang menghasilkan beras, termasuk jenis Oryza (ada banyak macam dan namanya; (2) butir dan buah padi. Dalam kaitannya dengan leksikon jagung, kata pari tersebut digunakan untuk mengelompokkan jagung yang bijinya seperti butiran padi. Kata kristal memiliki arti (1) hablur; (2) unsur pembentukan batuan yang atomnya tersusun dan terikat oleh kekuatan intermolekuler sehingga menjadi padat. Dalam kaitannya dengan leksikon jagung, kata kristal digunakan petani untuk mengelompokkan jagung yang memiliki biji mirip dengan batuan kristal. Kata unyil berasal dari kata 'mungil', memiliki arti (1) kecil elok, molek; (2) lucu menarik hati 
karena eloknya (tentang kanak-kanak). Dalam kaitannya dengan leksikon jagung, kata unyil digunakan oleh masyarakat untuk mengelompokkan jagung karena bijinya yang berukuran kecil. Selanjutnya, kata kertas dapat diasumsikan sebagai barang lembaran dibuat dari bubur rumput, jerami, kayu dan sebagainya yang biasa ditulisi atau untuk pembungkus dan sebagainya. Kaitannya dengan penamaan jagung oleh masyarakat ialah bobotnya yang ringan sehingga jagung yang dihasilkan disebut sebagai jagung kertas.

Leksikon jagung yang memiliki unsur kata dalam membentuk atribut ialah jagung canthel, jagung pakan, jagung manis, jagung genjah, jagung metro, dan jagung jalawara. Seluruh jagung tersebut merupakan jagung varietas lokal yang saat ini kehadirannya sudah jarang ditemui. Kata canthel berasal dari bahasa Jawa, memiliki arti arane tetuwuhan bangsa jali 'sebutan tumbuhan sebangsa biji-bijian'. Jagung jenis canthel ini jarang dikategorikan sebagai jenis jagung karena bentuk fisik tanamannya mirip sorgum. Kata pakan berasal dari bahasa Jawa yang memiliki arti (1) pangan utawa ingon tumrap kewan 'makanan untuk hewan'; (2) apa-apa sing dilebokake ing geni, gilingan, lan saperlune 'apa saja yang dimasukkan ke dalam perapian, penggilingan, dan lain sebagainya'; (3) sing dipasangake supaya dipangan (tumrap pancing) 'apa saja yang dipasang agar dimakan (khusus alat pemancingan); (4) sing dianggo isen-isen malang (tumrap tenunan, nam-naman, lan saperlune 'yang dipakai sebagai isi malang (khusus tenun, kerajinan anyam, dan lain sebagainya). Kaitannya dengan leksikon jagung, jagung pakan ditanam masyarakat untuk dimanfaatkan sebagai makanan burung. Kata jalawara merupakan varietas lokal tanaman jagung yang dibudidayakan melalui lingkungan setempat. Kata manis berarti (1) rasa seperti gula; (2) elok; mungil (tentang gadis, benda); (3) sangat menarik hati (tentang muka, senyum, perkataan, dan sebagainya; (4) indah, menyenangkan. Kaitannya dengan leksikon jagung, jagung manis dikelompokkan berdasarkan rasanya yang dinilai manis. Kata metro mengacu pada benih jagung lokal yang bukan benih hibrida dan peka terhadap penyakit bulai. Kata genjah dalam bahasa Indonesia mengandung arti 'lekas berbuah'. Kaitannya dengan leksikon jagung, masyarakat menamakan jagung genjah karena waktu tanam yang singkat dan cepat berbuah.

Leksikon jagung yang masih dipertahankan hingga sekarang ialah jagung hibrida. Kata hibrida merupakan istilah biologi berupa hasil turunan yang berasal dari perkawinan antara dua jenis yang berlainan. Dalam penamaannya, masyarakat tidak secara terang menyebut varietas jagung hibrida, sehingga muncul beberapa penamaan jagung yang sebenarnya merupakan varietas dari jagung hibrida. Jagung hibrida berunsur kata yang dimaksud ialah jagung pioner. Kata pioner adalah istilah benih jagung yang dikeluarkan oleh PT. DuPont Indonesia. Benih jagung hibrida Pioneet telah ada di pasaran Indonesia sejak tahun 1986 dan merupakan pemimpin pasar dalam industri benih jagung hibrida.

Leksikon jagung berunsur kata lainnya memiliki unsur pusat berupa frasa dan atribut yang terdiri dari satu kata, seperti jagung blorok genjah, jagung blorok jero, jagung genjah kencur, jagung genjah menthel, jagung putih genjah. Unsur pusat yang berupa frasa menunjukkan adanya varietas yang dimiliki dari leksikon jagung, seperti jagung blorok, jagung genjah, dan jagung putih. Leksikon jagung blorok genjah memiliki unsur pusat jagung blorok dan atribut berunsur kata genjah. Kata genjah sudah diterangkan sebelumnya, kaitannya dengan leksikon jagung digunakan untuk mengetahui masa tanam jagung yang cepat dan lekas berbuah. Kata jero berasal dari bahasa Jawa yang berarti 'dalam'. Kata tersebut digunakan sebagai unsur pembeda dalam hal penanaman benih jagung yang ditanam secara dalam-dalam.

Leksikon jagung yang berunsur pusat frasa lainnya ialah jagung genjah kencur dan jagung genjah menthel. Kata kencur memiliki arti (1) tanaman yang mempunyai akar batang yang tertanam di dalam tanah, biasa dipakai untuk bahan rempah-rempah dan ramuan obat, (2) umbi kencur. Kaitannya dengan leksikon jagung, jagung genjah kencur dikelompokkan berdasarkan waktu tanam yang singkat seperti tanaman kencur. Kata menthel dalam bausastra Jawa digunakan dalam percakapan yang bermakna mrenthel 'bisa menabung'. Kata tersebut belum dapat dijelaskan lebih lanjut dalam kaitannya dengan leksikon jagung.

Salah satu karakteristik taksonomi yang nampak pada tanaman jagung ialah ditemukannya subvarietal setelah varietal sehingga secara generik memiliki enam jenjang. Hal ini dalam frasa nomina yang berunsur pusat jagung namun diikuti oleh gabungan kata lainnya sebagai unsur klasifikasi. Unsur pusat berbentuk kata majemuk ialah jagung putih genjah kodhok dan jagung putih genjah penjalin. Frasa putih genjah menun- 
jukkan varietas dan kata kodhok maupun penjalin menunjukkan adanya subvarietal pada leksikon jagung. Pengamatan awal ini, baru ditemukan jenis subvarietal yang berasal dari jenis jagung putih.

Secara harfiah, kata kodhok dan penjalin memiliki makna leksikal tersendiri. Kata kodhok berasal dari bahasa Jawa 'katak', yang memiliki arti binatang amfibi pemakan serangga yang hidup di air tawar atau di daratan, berkulit licin, berwarna hijau atau merah kecokelat-cokelatan, kaki belakang lebih panjang daripada kaki depan, pandai melompat dan berenang. Kata kodhok kaitannya dengan leksikon jagung ialah masa tanam yang dimanfaatkan oleh tanaman tersebut dapat dilakukan pada dua musim, yakni musim kemarau dan musim penghujan. Layaknya kehidupan katak yang dapat hidup di daratan maupun perairan. Kata penjalin berasal dari bahasa Jawa yang memiliki arti 'rotan (biasanya dibuat perabot rumah tangga)'. Kaitannya dengan leksikon jagung ialah buah yang dihasilkan kecil dan ramping, layaknya rotan yang dinamakan penjalin.

Berdasarkan pembahasan unsur pembentuk atribut proses pembentukan leksikon jagung ditunjukkan pada Bagan 1.

\section{Unsur Pembentuk Atribut Berunsur Frasa}

Leksikon jagung berunsur frasa yang dimaksud memiliki unsur pusat kata jagung dan atribut yang berupa frasa. Berdasarkan penelitian yang telah dilakukan, atribut yang berupa frasa berasal dari varietas jagung hibrida. Berdasarkan unsur pembentuk atribut berupa frasa dapat digambarkan melalui Bagan 2.

Varietas jagung hibrida terdiri atas jagung tongkol dua, jagung tongkol tiga, jagung tongkol empat. Varietas tersebut berasal dari jagung hibrida yang menghasilkan lebih dari satu tongkol, tongkol yang dihasilkan yakni dua, tiga, dan empat. Tongkol pada tanaman jagung terdapat di antara batang daun dengan pelepah daun. Secara umum, dalam satu tanaman jagung hanya dapat menghasilkan satu buah tongkol yang produktif. Hal ini berkaitan dengan hasil penyerbukan yang dilakukan oleh bunga jantan dan bunga betina. Tanaman jagung memiliki sejumlah bunga betina dan bunga jantan mampu melakukan penyerbukan sebanyak dua hingga lima hari lebih dulu dari pada bunga betinanya. Penggunaan atribut jumlah tersebut tidak menyertakan jumlah satu atau sebuah karena tanaman jagung yang berbuah satu sudah umum dihasilkan sehingga masyarakat menggunakan jumlah buah yang tidak biasa dari jagung biasanya.

Varietas jagung lainnya berasal dari jagung hibrida dapat dibedakan berdasarkan jenis benihnya adalah jagung bisi 2 dan jagung bisi 18. Kategori atribut jumlah yang muncul adalah berupa penulisan angka 2 dan 18. Kedua leksikon jagung tersebut mengalami penghilangan unsur 'hibrida' karena anggapan masyarakat modern yang sudah terbiasa menghasilkan varietas hibrida daripada varietas lokal. Saat ini, jagung hibrida sangat digemari oleh petani jagung karena dengan benih sebanyak $1 \mathrm{Kg}$ bisa menghasilkan kurang lebih 5 ton. Efek kemunculan penanaman jagung hibrida

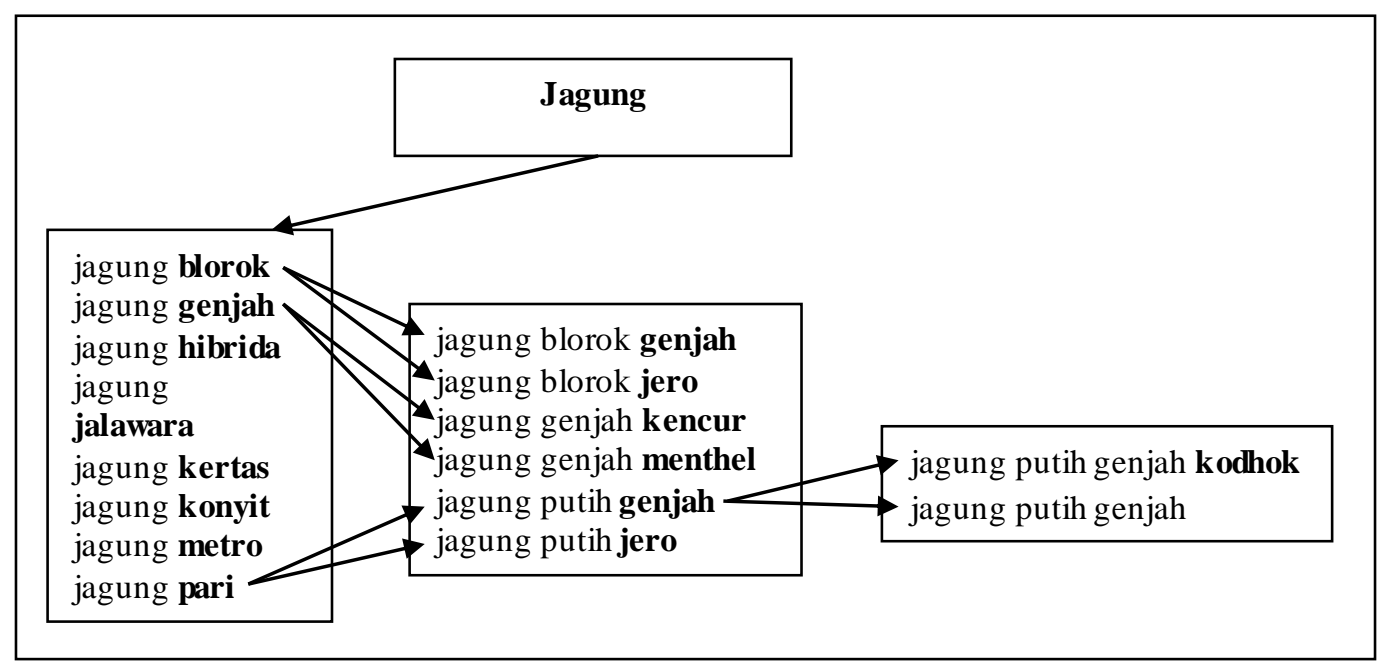

Bagan 1. Leksikon Jagung Berunsur Kata 
tersebut di beberapa daerah sudah jarang ditemukan varietas lokal tanaman jagung, seperti jagung putih dan jagung unyil. Penelitian ini menjadi langkah inventarisasi jenis jagung tradisional sebelum punah dan tidak dikenali oleh masyarakat.

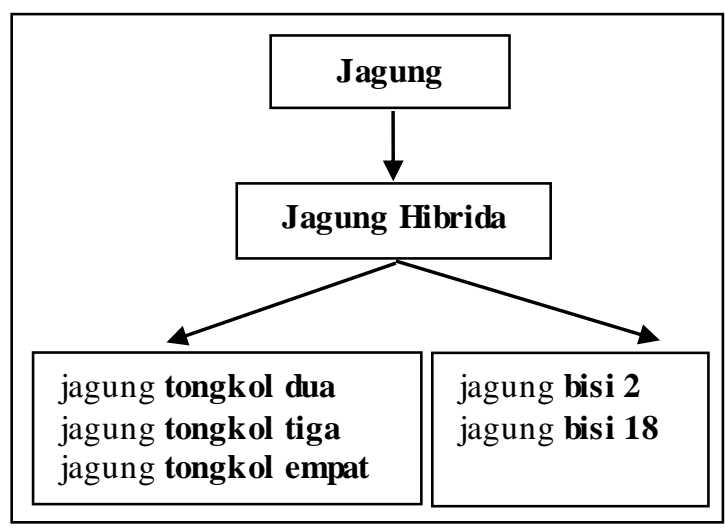

Bagan 2. Leksikon Jagung Berunsur Frasa

Bahasa yang digunakan dalam pembentukan atribut leksikon jagung tidak terpaku pada satu bahasa saja, melainkan ada yang menggunakan bahasa Jawa, bahasa Indonesia, maupun bahasa Indonesia dalam peristilahan ilmiah (khusus ilmu biologi). Dalam penelitian ini fungsi atribut hanya dipaparkan secara umum berdasarkan makna referensialnya. Penelitian lebih lanjut, atribut dapat dijelaskan sebagai kategorisasi atau klasifikasi penamaan masyarakat terhadap jagung berdasarkan cara budi daya di lingkungannya.

\section{Jenis Referen Pembentuk Atribut}

Masyarakat Jawa dalam penyebutan leksikon jagung menggunakan bahasa Jawa maupun bahasa Indonesia serta istilah ilmiah biologi. Penggunaan bahasa Jawa dalam masyarakat Jawa menamai jagung berkaitan dengan bahasa ibu yang digunakan oleh penutur. Penggunaan bahasa Indonesia oleh petani Jawa disebabkan adanya pengaruh pihak luar, seperti pemerintah, dalam hal ini diwakili oleh pertanian dan perhutani yang memberikan penamaan jagung secara kolektif. Walaupun dalam penerapannya, penamaan jenis jagung yang berasal dari pemerintah tersebut memiliki perbedaan penamaan oleh masyarakat Jawa. Hal ini berkaitan dengan acuan secara khusus yang digunakan dalam penggolongannya. Jenis referensi yang digunakan terdiri dari tiga kategori, yakni (1) berdasarkan fungsi tanaman, (2) morfologi tanaman jagung, dan (3) cara budidaya tanaman jagung.

\section{Referen Berupa Fungsi Tanaman Jagung}

Salah satu pembeda dalam klasifikasi antara ilmu biologi dan klasifikasi yang dilakukan oleh masyarakat adalah munculnya fungsi tanaman. Fungsi yang dimaksud berupa manfaat tanaman yang diberdayakan oleh masyarakat, kemudian fungsi tersebut dapat menonjol dan dijadikan nama sebuah tanaman. Leksikon jagung yang dimaksud adalah jagung pakan. Jagung tersebut dikenal oleh masyarakat Pemalang sebagai makanan hewan dan dapat diolah menjadi bahan makanan lain, misalnya tepung. Selain itu, masyarakat Sragen mengenal adanya jagung manis karena rasanya yang manis serta fungsinya yang berperan penting sebagai sayuran atau dapat diolah untuk makanan.

\section{Referen Berupa Morfologi Tanaman Jagung}

Secara morfologi, masyarakat Jawa mengklasifikasikan tanaman jagung melalui benih, ukuran biji, ukuran buah, jumlah buah yang dihasilkan, warna biji dan warna buah, dan rasa yang dihasilkan buah. Leksikon jagung diklasifikasi melalui jenis benihnya adalah jagung bisi 2 dan jagung bisi 18. Jenis jagung bisi 18 memiliki nama lengkap biji jagung super hibrida bisi 18 dengan ciri-ciri lebih berbobot, warna biji yang mengkilat oranye kekuningan. Dalam satu tongkol, rata-rata berat bijinya mencapai 223 gram, sedangkan berat tongkolnya rata-rata 242 gram. Dengan melihat perbandingan berat biji per tongkol dengan berat tongkolnya seperti itu, maka bisa ditebak bahwa jagung ini memiliki ukuran tongkol yang kecil. Jenis jagung bisi 2 memiliki nama lengkap jagung hibrida bisi 2. Tanaman jagung hibrida bisi 2 akan mengeluarkan 2 tongkol jagung yang bisa dimanfaatkan petani, baik sebagai jagung pipil atau sebagai jagung sayur (babycorn). Kemampuan adaptasi jagung hibrida bisi 2 terhadap kondisi lingkungan yang sangat baik membuat jagung hibrida bisi 2 bisa ditanam di lahan manapun di Indonesia.

Leksikon berdasarkan ukuran biji dapat membedakan jagung unyil dan jagung kristal melalui perbedaan ukuran biji yang dihasilkan tanaman jagung. Perbedaan tersebut nampak pada ukuran biji dari jagung kristal yang lebih besar ukurannya dari jagung unyil. Karena ukuran biji jagung yang kecil, masyarakat petani jagung di Kabupaten Sragen menyebut jagung tersebut sebagai jagung unyil. Masyarakat Pemalang meng- 
golongkan jagung manis masuk ke dalam sayuran dengan ciri-ciri secara morfologi memiliki tongkol kecil, sejenis hortikultura, dan batangnya tumbuh lebih pendek dari jagung pakan. Leksikon jagung berdasarkan jumlah buah yang dihasilkan berupa jagung tongkol dua, jagung tongkol tiga, dan jagung tongkol empat. Klasifikasi berdasarkan warna biji atau buah nampak pada leksikon jagung konyit, jagung putih, dan jagung blorok.

\section{Referen Berupa Cara Budi Daya Tanaman Jagung}

Klasifikasi berdasarkan cara pembudidayaan, seperti kedalaman benih jagung, yakni jagung putih jero dan jagung hibrida sebagai hasil persilangan antara kedua jenis jagung yang berbeda. Suhandano (2007:296) mengemukakan bahwa salah satu kekhasan yang dimiliki tanaman jagung dalam bahasa Jawa ialah munculnya penamaan jagung pada kategori subvarietal. Kategori tersebut muncul berdasarkan karakteristik fisik dan umur tumbuhan sehingga jenis klasifikasi pada jagung tidak murni klasifikasi taksonomi. Keunikan referen leksikon jagung yang nampak adalah dalam satu leksikon bisa menandai lebih dari satu referen contoh jagung putih genjah penjalin. Kata putih mengacu pada warna buah atau biji yang dihasilkan, kata genjah mengacu pada umur tanaman jagung (berumur pendek), kata penjalin mengacu pada rotan (biasanya dibuat perabot rumah tangga).

Adanya referen yang beragam dalam leksikon jagung menjelaskan keunikan bahasa Jawa yang tampak tumpang tindih antara klasifikasi taksonomi dan klasifikasi berdasarkan umur (Suhandano, 2007). Selain itu, kosakata yang digunakan sebagai atribut dapat berasal dari kosakata flora maupun fauna yang berasal dari lingkungan masyarakat Jawa, seperti kodhok dan penjalin. Ditemukan adanya perbedaan leksikon jagung antara penelitian terdahulu dengan data awal di beberapa daerah, seperti Kabupaten Sragen dan Pemalang. Hal ini menunjukkan adanya

\section{DAFTAR PUSTAKA}

Djajasudarma, T. F. 2012. Semantik 1: Makna Leksikal dan Gramatikal. Bandung: PT. Refika Aditama.

Haryanti, D. \& A. B. Wahyudi. 2007. Ungkapan Etnis Petani Jawa di Desa Japanan, Kecamatan perbedaan pandangan masyarakat terhadap satu lingkungan yang sama seperti tanaman jagung.

Perbedaan tersebut tidak menjadi hal yang signifikan karena leksikon jagung yang ditemukan memiliki klasifikasi tumpang tindih di dalam pandangan masyarakat Jawa. Diperlukan penelitian lebih lanjut untuk mengetahui klasifikasi secara umum tentang leksikon jagung yang muncul di berbagai daerah di Jawa. Klasifikasi tersebut dapat menjelaskan bukan sebatas leksikon saja, namun juga cara budi daya tanaman jagung, seperti proses penanaman hingga pascapanen yang dilakukan oleh masyarakat Jawa.

\section{SIMPULAN}

Hasil peneltian menunjukkan adanya dua pokok temuan, yakni unsur pembentuk atribut dan jenis referen pembentuk atribut. Unsur pusat dalam leksikon jagung dapat terdiri atas kat dan frasa. Jenis referen atribut terdiri dari tiga kategori, yakni secara fungsi tanaman, morfologi tubuh tanaman jagung, dan cara budi daya tanaman jagung. Leksikon jagung dalam masyarakat Jawa tidak dibatasi pada satu bahasa saja. Hasil penelitian menunjukkan penggunaan bahasa Jawa dan bahasa Indonesia pada atribut pembentuk leksikon jagung. Penggunaan bahasa Indonesia dapat dikhususkan pada istilah-istilah ilmiah dalam ilmu biologi. Temuan penelitian ini memerlukan adanya penelitian lebih mendalam untuk membedakan bagian tubuh tanaman jagung, seperti biji dan buah serta cara budi daya untuk mengklasifikasi tanamana jagung pada masyarakat Jawa.

\section{UCAPAN TERIMA KASIH}

Penulis menyampaikan ucapan terima kasih kepada mitra bestari (reviewers) yang telah memberikan saran, kritik, dan rekomendasi perbaikan artikel ini. Ucapan terima kasih diberikan pula kepada informan yang telah membantu pelaksanaan penelitian ini.

Cawas, Kabupaten Klaten: Kajian Etnolinguistik. Jurnal Kajian Linguistik dan Sastra, 19 (1): 35-50.

Parera, J. D. 1993. Leksikon Istilah Pembelajaran Bahasa. Jakarta: Gramedia. 
Parera, J. D. 2004. Teori Semantik. Jakarta: Penerbit Erlangga.

Sugono, D., dkk. 2008. Kamu Besar Bahasa Indonesia. Jakarta: Gramedia.

Suhandano. 2000. Klasifikasi Folk Biologi dalam Bahasa Jawa Sebuah Pengamatan Awal. Jurnal Humaniora, 12 (2): 225-230.

Suhandano. 2004. Klasifikasi Tumbuh-Tumbuhan dalam Bahasa Jawa: Sebuah Kajian Linguistik Antropologis. Disertasi. Yogyakarta: Universitas Gadjah Mada.

Suhandano. 2007. Kategori Tumbuh-Tumbuhan Wit dan Suket dalam Bahasa Jawa. Jurnal Humaniora, 19 (1): 89-97.

Suhandano, dkk. 2004. Leksikon Etnobotani Bahasa Jawa. Jurnal Humaniora, 16 (3): 229-241.

Sudaryanto. 2015. Metode dan Aneka Teknik Analisis Bahasa. Yogyakarta: Sanata Dharma University Press.
Tim Balai Bahasa Yogyakarta. 2011. Kamus Basa Jawa (Bausastra Jawa). Yogyakarta: PT. Kanisius.

Tondo, F. H. 2012. Bahasa Minoritas Hamap dalam Perkebunan Jagung: Tinjauan Etnoinguistik. Jurnal Pendidikan dan Kebudayaan, 18 (2): 204-215.

Verhaar, J. W. M. 2012. Asas-Asas Linguistik Umum. Yogyakarta: Gadjah Mada University Press.

Verhaar, J.W.M. 1981. Pengantar Linguistik Jilid I.. Yogyakarta: Gadjah Mada University Press.

Wijana, I D. P. 2015. Pengantar Semantik Bahasa Indonesia. Yogyakarta: Program Studi Linguistik, Fakultas Ilmu Budaya, Universitas Gadjah Mada.

Wijana, I D. P. 2016. Metode Linguistik: Identifikasi Satuan-Satuan Lingual. Yogyakarta: A.Com Advertising. 